\title{
Hepatocellular Carcinoma in a Patient With Crohn's Disease
}

Akira Hokama ${ }^{1}$, Shingo Arakaki ${ }^{2}$, Shinichiro Ishino ${ }^{3}$, Yutaka Nakagawa ${ }^{3}$, Souhei Tabata ${ }^{2}$, Daiki Agarie $^{2}$ , Satoshi Kuwae ${ }^{2}$, Ryuta Zukeyama ${ }^{2}$, Tatsuji Maeshiro ${ }^{2}$, Yuma Tsuruta ${ }^{4}$, Akiko Matsuzaki ${ }^{4}$, Naoki Wada ${ }^{5}$, Mitsuhisa Takatsuki ${ }^{3}$, Jiro Fujita ${ }^{2}$

1. Department of Endoscopy, Graduate School of Medicine, University of the Ryukyus, Nishihara, JPN 2. Department of Infectious, Respiratory, and Digestive Medicine, Graduate School of Medicine, University of the Ryukyus, Nishihara, JPN 3. Department of General and Digestive Surgery, Graduate School of Medicine, University of the Ryukyus, Nishihara, JPN 4. Department of Pathology, University of the Ryukyus Hospital, Nishihara, JPN 5. Department of Pathology and Oncology, Graduate School of Medicine, University of the Ryukyus, Nishihara, JPN

Corresponding author: Akira Hokama, hokama-a@med.u-ryukyu.ac.jp

\begin{abstract}
A 44-year-old woman with a 26-year history of Crohn's disease (CD) presented with intermittent fever, vomiting, and watery diarrhea. Her medication included an elemental diet, mesalazine, and infliximab. Liver profile and viral hepatitis markers were normal. Computed tomography scans showed a hepatic tumor by chance. Serum tumor markers disclosed elevated protein induced by vitamin $\mathrm{K}$ absence-II. With a diagnosis of hepatocellular carcinoma (HCC), she underwent a hepatic resection of the tumor, revealing well-tomoderately differentiated HCC. The nontumor region of the liver disclosed the absence of cirrhosis or other diseases. Here, the development of HCC in CD without underlying liver diseases is discussed with a review of the literature.
\end{abstract}

Categories: Gastroenterology, Oncology

Keywords: hepatocellular carcinoma, infliximab, pathology, computed tomography, crohn's disease (cd)

\section{Introduction}

The development of hepatocellular carcinoma (HCC) is mostly associated with underlying liver diseases, such as cirrhosis and chronic hepatitis. Crohn's disease (CD) is often complicated with various hepatobiliary disorders, including cholelithiasis and abnormal liver function [1]. Recently, several cases of HCC have been reported among $\mathrm{CD}$ patients without cirrhosis, and immunosuppressive treatments for $\mathrm{CD}$ have been focused on as potential carcinogenic factors. Here, we present the case of a patient with $\mathrm{CD}$ who developed HCC in the absence of underlying liver diseases and discuss the background of carcinogenesis.

Review began 07/11/2021 Review ended 07/14/2021 Published 07/22/2021

\section{(c) Copyright 2021}

Hokama et al. This is an open access article distributed under the terms of the Creative Commons Attribution License CC-BY 4.0., which permits unrestricted use, distribution, and reproduction in any medium, provided the original author and source are credited.

\section{Case Presentation}

A 44-year-old woman with a 26-year history of CD presented with intermittent fever, vomiting, and watery diarrhea. Her medical history was significant for a colonic resection at the age of 40 and a proctocolectomy with end ileostomy at the age of 41 . Her medication included an elemental diet, mesalazine $3 \mathrm{~g}$ daily, and infliximab (IFX) $10 \mathrm{mg} / \mathrm{kg}$ every eight weeks. She denied smoking and alcohol use. Physical examination revealed stable vital signs and a body mass index of $17.9 \mathrm{~kg} / \mathrm{m}^{2}$. The abdomen was soft and nontender. Laboratory tests showed white blood cells of 5,700/ $\mu \mathrm{L}$, hemoglobin of $10.1 \mathrm{~g} / \mathrm{dL}$, platelets of $32.5 \times 10^{4} / \mu \mathrm{L}$, and C-reactive protein of $0.85 \mathrm{mg} / \mathrm{dL}$ (reference range: $<0.23 \mathrm{mg} / \mathrm{dL}$ ). Liver profile and viral hepatitis markers were normal: bilirubin $0.4 \mathrm{mg} / \mathrm{dL}$ (reference range: $0.4-1.5 \mathrm{mg} / \mathrm{dL}$ ), aspartate aminotransferase 20 U/L (reference range: 13-30 U/L), alanine aminotransferase $35 \mathrm{U} / \mathrm{L}$ (reference range: 7-23 U/L), alkaline phosphatase $158 \mathrm{U} / \mathrm{L}$ (reference range: 106-322 U/L), lactate dehydrogenase $120 \mathrm{U} / \mathrm{L}$ (reference range: 124$222 \mathrm{U} / \mathrm{L}$ ), and gamma-glutamyl transferase $11 \mathrm{U} / \mathrm{L}$ (reference range: 9-32 U/L). Computed tomography (CT) scans were performed to evaluate the symptoms, which showed a hepatic tumor incidentally. A CT scan showed a heterogeneously enhancing hepatic tumor at the arterial phase (Figure 1). 


\section{Cureus}

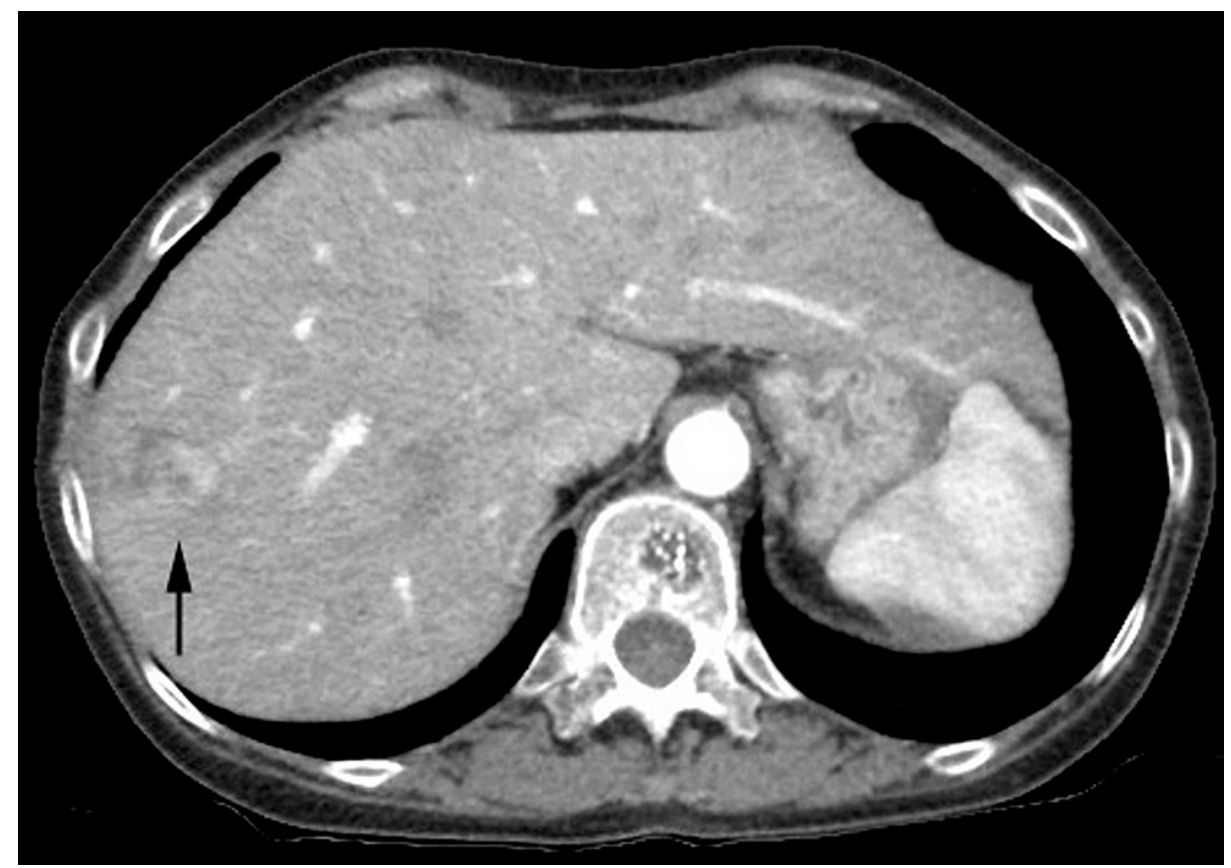

\section{FIGURE 1: Abdominal CT.}

CT scan showing a heterogeneously enhancing hepatic tumor (arrow) at the arterial phase.

CT: computed tomography

Gadolinium ethoxybenzyl diethylenetriamine pentaacetic acid-enhanced magnetic resonance imaging showed the hyperintense tumor on T2-weighted imaging (Figure 2).

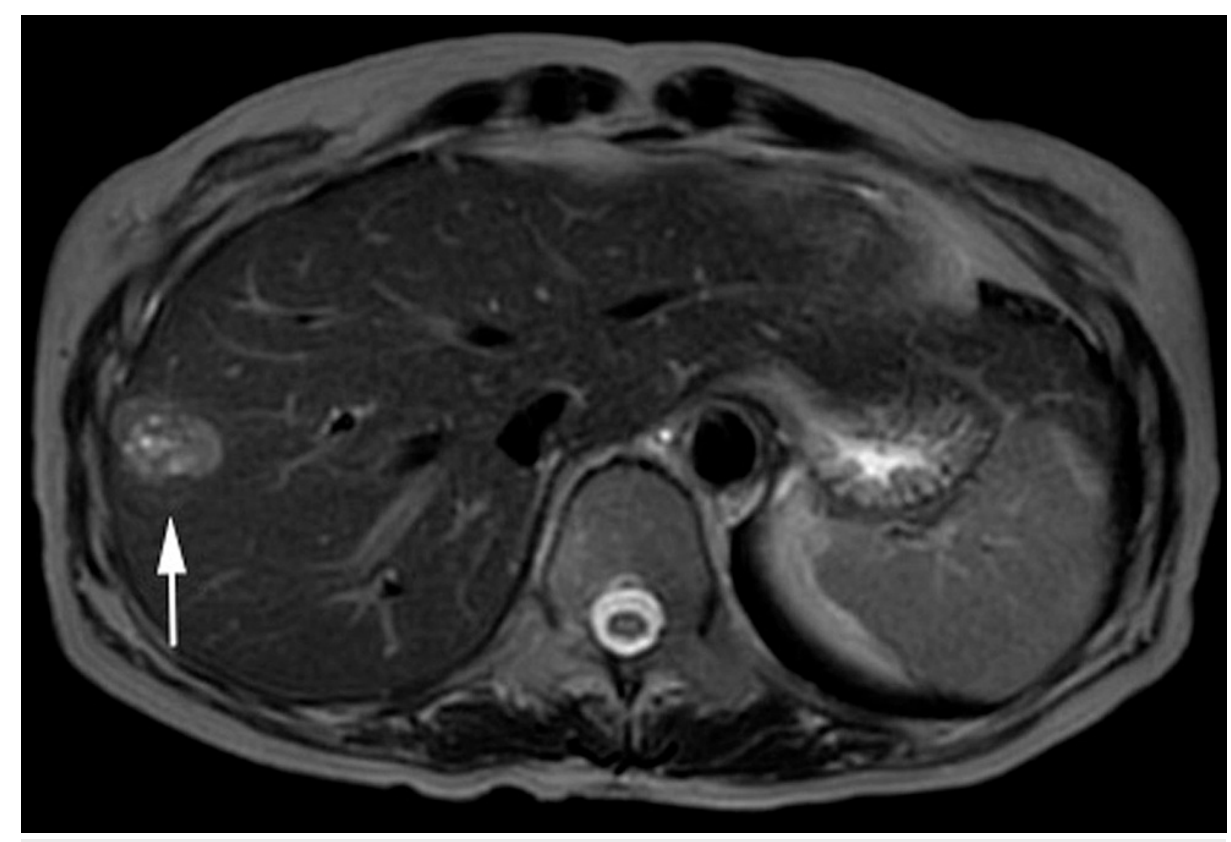

FIGURE 2: Abdominal MRI.

Gadolinium ethoxybenzyl diethylenetriamine pentaacetic acid-enhanced MRI showed the 28-mm-sized hepatic tumor (arrow) on T2-weighted imaging.

MRI: magnetic resonance imaging

Serum tumor markers showed $\alpha$-fetoprotein of $7 \mathrm{ng} / \mathrm{mL}$ (reference range: $<9 \mathrm{ng} / \mathrm{mL}$ ) and elevated protein 


\section{Cureus}

induced by vitamin $\mathrm{K}$ absence-II of 1,411 $\mathrm{mAU} / \mathrm{mL}$ (reference range: $<40 \mathrm{mAU} / \mathrm{mL}$ ). $\mathrm{HCC}$ was suspected based on laboratory and imaging studies. She underwent a hepatic resection of the tumor with an uncomplicated postoperative course. Pathological examination of the tumor showed well-to-moderately differentiated HCC without evidence of microvascular invasion (Figure 3). The non-neoplastic liver showed no evidence of chronic hepatitis, liver cirrhosis, or other metabolic disorders (Figure 4).

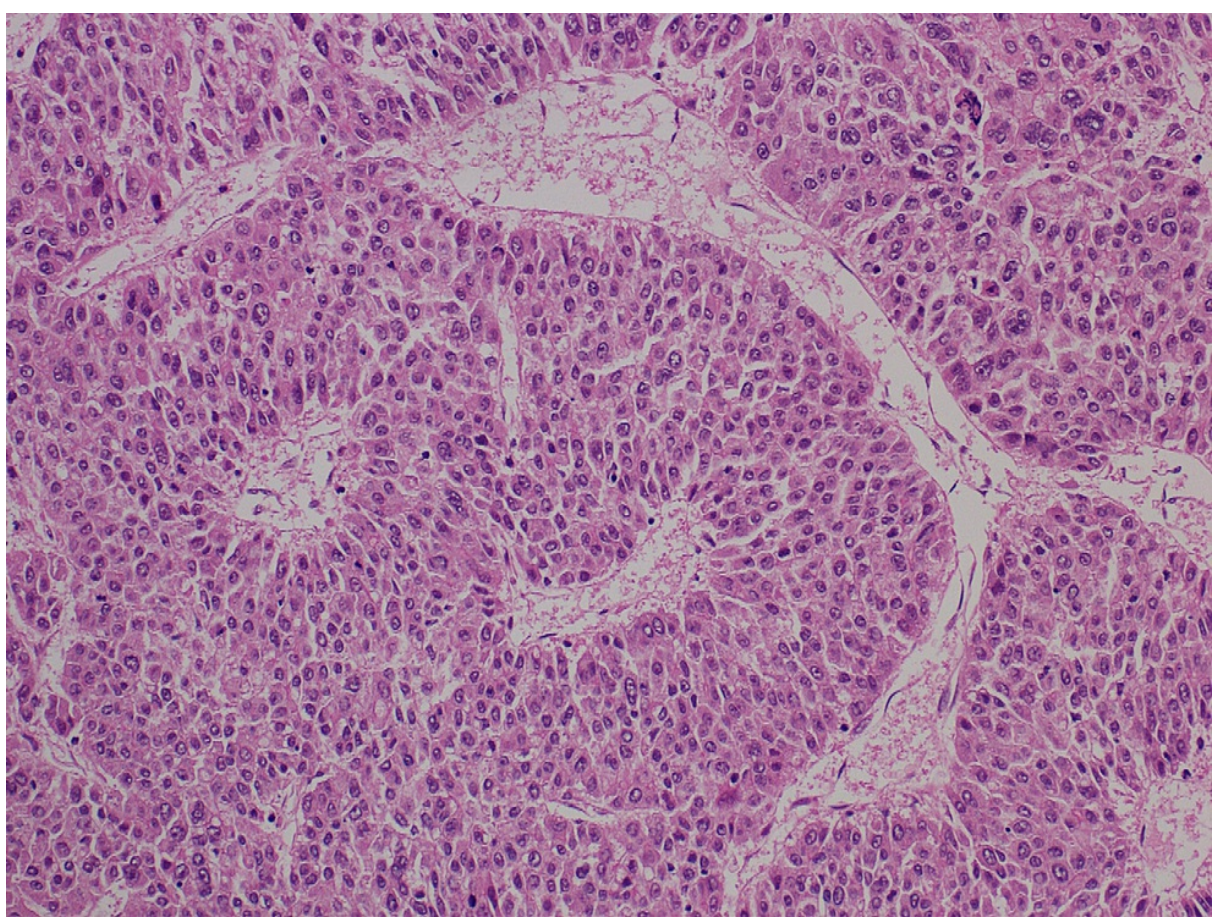

FIGURE 3: Histopathological figure.

Histopathological findings of the tumor showed well-to-moderately differentiated HCC without evidence of microvascular invasion (hematoxylin and eosin staining, magnification: $\times 200$ ).

HCC: hepatocellular carcinoma 


\section{Cureus}

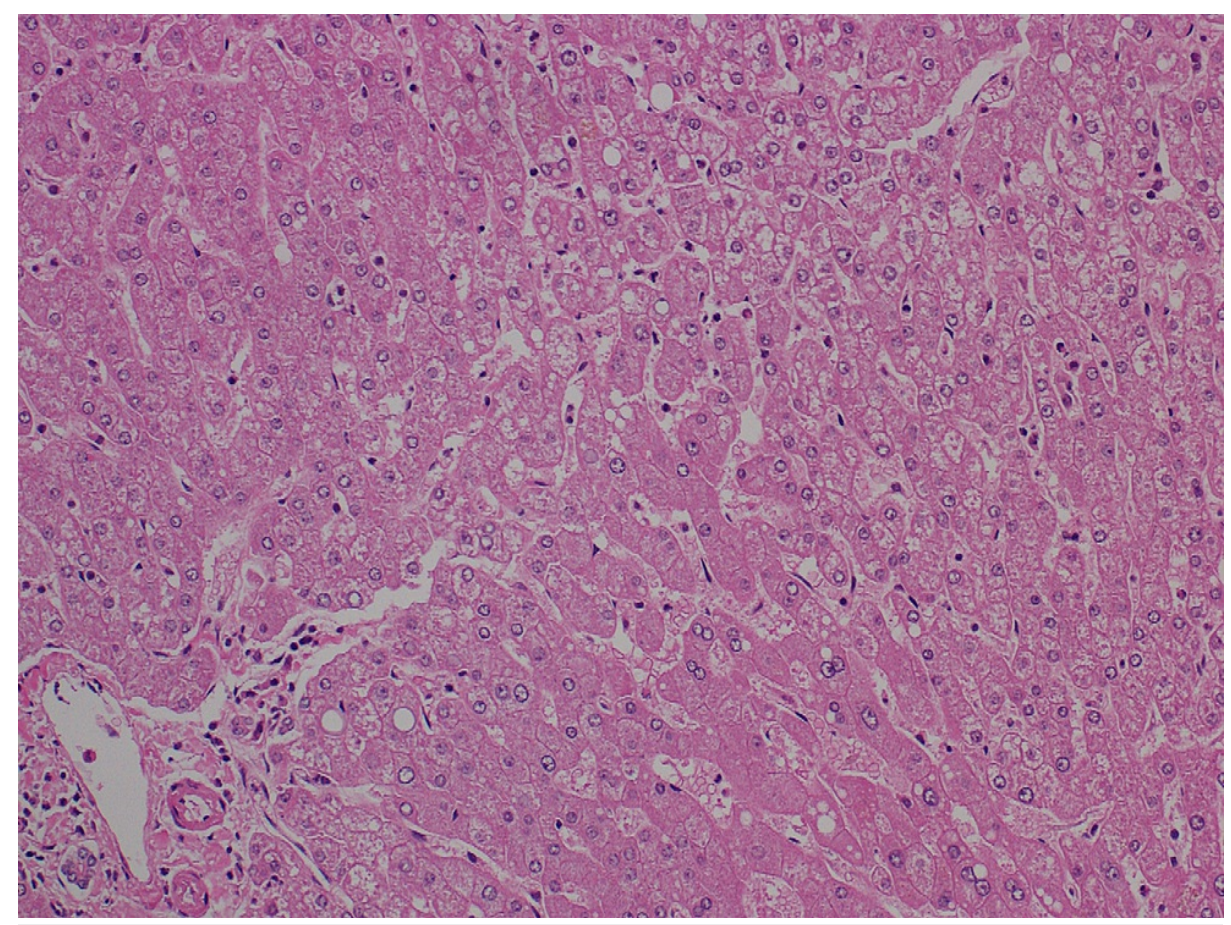

\section{FIGURE 4: Histopathological figure.}

The nontumor region of the liver disclosed the absence of cirrhosis or other diseases (magnification: $\times 200$ ).

IFX was discontinued because of the potential effects in post-cancer surgery and vedolizumab was initiated. The patient has been free from recurrence for two years.

\section{Discussion}

Most HCC cases develop in the presence of cirrhosis or hepatitis. This case presents important clinical issues that HCC can occur in patients with CD, even without underlying liver diseases for HCC. The occurrence of HCC among patients with CD is extremely rare, with only 15 cases, including our case, published as case reports in the literature [2-15].

Table 1 summarizes the clinicopathological features of HCC in CD patients. The average age of the diagnosis of HCC among these CD patients was 40.6 years, which was younger than that of usual HCC (50 years) [16]. The average period between the onset of CD and the diagnosis of HCC was 19.3 years. Several hepatic diseases have been reported in association with $\mathrm{CD}$, which include cholelithiasis, primary sclerosing cholangitis (PSC), steatosis, and drug-induced abnormal liver function [1]. A total of eight (53.3\%) cases, including the present case, had no underlying liver diseases; whereas two cases had PSC, four cases had focal hepatic glycogenosis (FHG), and one case had chronic liver inflammation. It is well known that both PSC and FHG have significant neoplastic potentials. 


\section{Cureus}

\begin{tabular}{|c|c|c|c|c|c|c|c|c|}
\hline $\begin{array}{l}\text { Case } \\
\text { No. }\end{array}$ & Gender & $\begin{array}{l}\text { Age: onset of } \\
\text { CD/discovery of } \\
\text { HCC }\end{array}$ & $\begin{array}{l}\text { Therapy } \\
\text { for } C D\end{array}$ & $\begin{array}{l}\text { Serum AFP/PIVKA II } \\
\text { (ng/mL, mAU/mL) }\end{array}$ & Pathology of HCC & $\begin{array}{l}\text { Pathology of non- } \\
\text { neoplastic liver }\end{array}$ & Therapy and outcome & $\begin{array}{l}\text { Reference } \\
\text { No. }\end{array}$ \\
\hline 1 & $\mathrm{~F}$ & $29 / 43$ & $\begin{array}{l}\text { AZA, } \\
\text { PSL }\end{array}$ & NA/NA & NA & No cirrhosis & $\begin{array}{l}\text { DOD with } \\
\text { carcinomatosis }\end{array}$ & [2] \\
\hline 2 & $\mathrm{~F}$ & $9 / 22$ & $\begin{array}{l}\text { 5-ASA, } \\
\text { AZA }\end{array}$ & $55,000 / \mathrm{NA}$ & Trabecular & $\begin{array}{l}\text { No cirrhosis } \\
\text { positive FHG }\end{array}$ & $\begin{array}{l}\text { Recurrence } 6 \text { months } \\
\text { after surgery }\end{array}$ & [3] \\
\hline 3 & $\mathrm{M}$ & $13 / 33$ & $\begin{array}{l}\text { 5-ASA, } \\
\text { AZA }\end{array}$ & NA/NA & NA & No cirrhosis & Lung metastasis & [4] \\
\hline 4 & $\mathrm{~F}$ & $63 / 63$ & 5-ASA & $\mathrm{NA} / 1,100$ & NA & PSC & $\begin{array}{l}\text { No recurrence } 15 \\
\text { months after LT }\end{array}$ & [5] \\
\hline 5 & $\mathrm{~F}$ & $14 / 28$ & AZA, IFX & 26.9/NA & $\begin{array}{l}\text { Trabecular, } \\
\text { pleomorphic }\end{array}$ & $\begin{array}{l}\text { No cirrhosis } \\
\text { positive FHG }\end{array}$ & Surgery & [6] \\
\hline 6 & $\mathrm{M}$ & $17 / 33$ & AZA & Normal range/NA & NA & PSC & $\begin{array}{l}\text { DOD with } \\
\text { carcinomatosis }\end{array}$ & [7] \\
\hline 7 & M & $19 / 37$ & $\begin{array}{l}\text { 5-ASA, } \\
\text { AZA, } \\
\text { PSL }\end{array}$ & 15/NA & $\begin{array}{l}\text { Trabecular to } \\
\text { sinusoidal, } \\
\text { pleomorphic }\end{array}$ & NA & $\begin{array}{l}\text { DOD } 3 \text { months after } \\
\text { onset }\end{array}$ & [8] \\
\hline 8 & M & $16 / 52$ & 5-ASA & $13.9 / 16,300$ & Trabecular & $\begin{array}{l}\text { Chronic liver } \\
\text { inflammation }\end{array}$ & $\begin{array}{l}\text { Recurrence after } \\
\text { TACE }\end{array}$ & [9] \\
\hline 9 & M & $13 / 25$ & $\begin{array}{l}\text { AZA, IFX, } \\
\text { PSL }\end{array}$ & 78/NA & Pleomorphic & $\begin{array}{l}\text { No cirrhosis } \\
\text { positive FHG }\end{array}$ & $\begin{array}{l}\text { No recurrence } 1 \text { year } \\
\text { after surgery }\end{array}$ & [10] \\
\hline 10 & M & $29 / 37$ & $\begin{array}{l}\text { 5-ASA, } \\
\text { AZA, } \\
\text { PSL }\end{array}$ & $7.7 / 757$ & Pseudoglandular & $\begin{array}{l}\text { No cirrhosis } \\
\text { positive FHG }\end{array}$ & $\begin{array}{l}\text { No recurrence } 2 \text { years } \\
\text { after surgery }\end{array}$ & [11] \\
\hline 11 & M & $9 / 34$ & AZA, IFX & $3307 / \mathrm{NA}$ & Trabecular & No cirrhosis & $\begin{array}{l}\text { Carcinomatosis; died } \\
5 \text { months after }\end{array}$ & [12] \\
\hline 12 & M & $20 / 58$ & $\begin{array}{l}\text { 5-ASA, } \\
\text { AZA }\end{array}$ & 10.3/NA & $\begin{array}{l}\text { Moderately } \\
\text { differentiated }\end{array}$ & No cirrhosis & $\begin{array}{l}\text { Recurrence } 4 \text { years } \\
\text { after surgery }\end{array}$ & [13] \\
\hline 13 & M & $20 / 40$ & IFX, ADA & NA/NA & $\begin{array}{l}\text { Moderately } \\
\text { differentiated }\end{array}$ & No cirrhosis & $\begin{array}{l}\text { Recurrence } 5 \text { years } \\
\text { after surgery }\end{array}$ & [14] \\
\hline 14 & $\mathrm{~F}$ & $31 / 61$ & $\begin{array}{l}\text { 5-ASA, } \\
\text { AZA, IFX }\end{array}$ & NA/NA & Well-differentiated & No fibrosis & $\begin{array}{l}\text { No recurrence } 11 \\
\text { months after surgery }\end{array}$ & [15] \\
\hline 15 & $\mathrm{~F}$ & $18 / 44$ & $\begin{array}{l}\text { 5-ASA, } \\
\text { IFX }\end{array}$ & $7 / 1,411$ & $\begin{array}{l}\text { Moderately } \\
\text { differentiated }\end{array}$ & No cirrhosis & $\begin{array}{l}\text { No recurrence } 2 \text { years } \\
\text { after surgery }\end{array}$ & $\begin{array}{l}\text { Present } \\
\text { case }\end{array}$ \\
\hline
\end{tabular}

\section{TABLE 1: Clinicopathological features of HCC in patients with CD.}

CD: Crohn's disease; AFP: alfa-fetoprotein; PIVKA-II: protein induced by vitamin K absence-II; HCC: hepatocellular carcinoma; AZA: azathioprine; PSL: prednisolone; NA: not available; DOD: died of disease; 5-ASA: 5-aminosalicylic acid; FHG: focal hepatocyte glycogenosis; LT: liver transplantation; PSC: primary sclerosing cholangitis; TACE: transcatheter arterial chemoembolization; ADA: adalimumab

Considering the association with the treatments for $\mathrm{CD}, 11$ (73.3\%) cases were treated with AZA, and six (40\%) cases were administered IFX. Although AZA has an increased risk of neoplasms including lymphoma and skin cancer, the association with HCC is unknown. The effects of IFX on the development of HCC have not been clarified. Several epidemiology investigations revealed no association between IFX and cancer risks [17,18]. Therefore, IFX may be an innocent bystander in HCC among patients with CD [12]. Although acute liver injury caused by immunosuppressants and biologics has been well studied in the treatment for CD [19], long-term hepatotoxicity and hepatocarcinogenesis should be further monitored carefully. In addition, a recent Swedish/Danish population-based cohort study (1969-2017) revealed 28 deaths from HCC among 47,399 patients with CD and corresponding hazard ratios (HRs) of 1.96 (95\% confidence interval: 1.31-2.93) [20]. Although this data lacked information on smoking, alcohol consumption, and underlying hepatic diseases, specific surveillance strategies for HCC was needed because of high HRs. 


\section{Conclusions}

In summary, we present a case of HCC in a patient with CD who was treated with IFX in the absence of underlying liver diseases. Although the precise pathophysiology of the development of HCC in CD has not been clarified and potential links should be further investigated, the liver should be surveyed closely by imaging studies in addition to routine blood tests in the era of immunosuppressive treatments with AZA or biologics.

\section{Additional Information \\ Disclosures}

Human subjects: Consent was obtained or waived by all participants in this study. Conflicts of interest: In compliance with the ICMJE uniform disclosure form, all authors declare the following: Payment/services info: All authors have declared that no financial support was received from any organization for the submitted work. Financial relationships: All authors have declared that they have no financial relationships at present or within the previous three years with any organizations that might have an interest in the submitted work. Other relationships: All authors have declared that there are no other relationships or activities that could appear to have influenced the submitted work.

\section{References}

1. Restellini S, Chazouillères O, Frossard JL: Hepatic manifestations of inflammatory bowel diseases . Liver Int. 2017, 37:475-89. 10.1111/liv.13265

2. Lee FL, Murray SM, Prior J, Shreeve DR: Primary liver cell cancer occurring in association with Crohn's disease treated with prednisolone and azathioprine. Hepatogastroenterology. 1983, 30:188.

3. Cattan S, Wendum D, Chazouilleres O, Schmitz J, Gendre JP: Hepatocellular carcinoma and focal hepatic glycogenosis after prolonged azathioprine therapy. Hum Pathol. 2000, 31:874-6. 10.1053/hupa.2000.7629

4. Borum ML: Unusual development of hepatocellular carcinoma in a patient with Crohn's disease . Dig Dis Sci. 2001, 46:2199-200. 10.1023/a:1011915032118

5. Oya H, Sato Y, Yamamoto S, Takeishi T, Kobayashi T, Hatakeyama K: Living related donor liver transplantation for primary sclerosing cholangitis with hepatocellular carcinoma and Crohn's disease: a case report. Transplant Proc. 2004, 36:2297-8. 10.1016/j.transproceed.2004.07.041

6. Chen SC, Cummings OW, Hartley MP, Filomena CA, Cho WK: Hepatocellular carcinoma occurring in a patient with Crohn's disease treated with both azathioprine and infliximab. Dig Dis Sci. 2006, 51:952-5. 10.1007/s10620-005-9009-9

7. Demarchi B, Bresso F, Novero D, et al.: Hepatocellular carcinoma complicating primary sclerosing cholangitis in Crohn's disease. A case report. Minerva Gastroenterol Dietol. 2007, 53:279-83.

8. Samarasena J, Borgaonkar M: Development of hepatocellular carcinoma in a patient with Crohn's disease treated with azathioprine. Dig Dis Sci. 2007, 52:2748-50. 10.1007/s10620-006-9613-3

9. Miura H, Kawaguchi T, Takazoe M, Kitamura S, Yamada H: Hepatocellular carcinoma and Crohn's disease: a case report and review. Intern Med. 2009, 48:815-9. 10.2169/internalmedicine.48.1866

10. Murakami A, Tanaka Y, Ueda M, et al.: Hepatocellular carcinoma occurring in a young Crohn's disease patient. Pathol Int. 2009, 59:492-6. 10.1111/j.1440-1827.2009.02399.x

11. Ishida M, Naka S, Shiomi H, et al.: Hepatocellular carcinoma occurring in a Crohn's disease patient . World J Gastroenterol. 2010, 16:3215-8. 10.3748/wjg.v16.i25.3215

12. Fortinsky KJ, Alali A, Jeejeebhoy K, Fischer S, Sherman M, Fung S: Metastatic hepatocellular carcinoma in a patient with Crohn's disease treated with azathioprine and infliximab: a case report and literature review. Case Rep Gastrointest Med. 2014, 2014:340836. 10.1155/2014/340836

13. Botros Y, Mathews M, Patel H, Shah N, Baddoura W, de la Torre A: Recurrent hepatocellular carcinoma in patient with Crohn's disease: incidental or expected outcome of azathioprine?. Case Rep Gastrointest Med. 2015, 2015:939136. 10.1155/2015/939136

14. Kumar A, Le DT: Hepatocellular carcinoma regression after cessation of immunosuppressive therapy . J Clin Oncol. 2016, 34:e90-2. 10.1200/JCO.2013.51.4067

15. Heron V, Fortinsky KJ, Spiegle G, Hilzenrat N, Szilagyi A: Resected hepatocellular carcinoma in a patient with Crohn's disease on azathioprine. Case Rep Gastroenterol. 2016, 10:50-6. 10.1159/000444012

16. Dimitroulis D, Damaskos C, Valsami S, et al.: From diagnosis to treatment of hepatocellular carcinoma: an epidemic problem for both developed and developing world. World J Gastroenterol. 2017, 23:5282-94. 10.3748/wig.v23.i29.5282

17. Biancone L, Petruzziello C, Orlando A, et al.: Cancer in Crohn's disease patients treated with infliximab: a long-term multicenter matched pair study. Inflamm Bowel Dis. 2011, 17:758-66. 10.1002/ibd.21416

18. Askling J, Fahrbach K, Nordstrom B, Ross S, Schmid CH, Symmons D: Cancer risk with tumor necrosis factor alpha (TNF) inhibitors: meta-analysis of randomized controlled trials of adalimumab, etanercept, and infliximab using patient level data. Pharmacoepidemiol Drug Saf. 2011, 20:119-30. 10.1002/pds.2046

19. Tran-Minh ML, Sousa P, Maillet M, Allez M, Gornet JM: Hepatic complications induced by immunosuppressants and biologics in inflammatory bowel disease. World J Hepatol. 2017, 9:613-26. 10.4254/wjh.v9.i13.613

20. Erichsen R, Olén O, Sachs MC, et al.: Hepatobiliary cancer risk in patients with inflammatory bowel disease: a Scandinavian population-based cohort study. Cancer Epidemiol Biomarkers Prev. 2021, 30:886-94. 10.1158/1055-9965.EPI-20-1241 